\title{
The reuse of the detention centre of Vilvoorde (Belgium): three centuries of convicts' graffiti
}

\author{
A. Verdonck ${ }^{1}$, D. Nuytten ${ }^{2} \&$ L. Dekeyser ${ }^{1}$ \\ ${ }^{I}$ Vrije Universiteit Brussel, Department of Architectural Engineering, \\ Brussels, Belgium \\ ${ }^{2}$ Department of Monuments and Sites of the Flemish Government, \\ Belgium
}

\begin{abstract}
The Detention Centre of Vilvoorde (Belgium) dates from 1773-1779 and is designed by Laurent Benoit Dewez, the royal architect of Charles-Alexandre de Lorraine. After some decades of lack of occupancy, the complex is to be reused for multiple purposes.

The most intact wing, where the cells are well-preserved, will serve as a museum, illustrating life in the $18^{\text {th }}$ century detention centre. Architectural paint research was executed in the cells of this former prison in preparation of the reuse assessment. On the walls of the extreme small vaulted cells, exposed graffiti represents in a unique way the isolated life of the detainees. As a result of the abominable state of preservation of these cell decorations, emergency fixations and restoration tests were executed. Here the building, its wellpreserved structure and spaces (with cells, corridors and large former workspaces-ateliers), its graffiti etc. will itself be the work of art on display, in combination with temporary exhibitions.

The other wings, where in the course of history much of the interior structure was lost, were reused as a modern living and working area. As such, the rehabilitation of the site of the detention centre acts as a pilot project in the reuse of a former industrial harbour area, which links the city of Vilvoorde to the Brussels business area.
\end{abstract}

Keywords: architectural paint research, graffiti, restoration strategy, retrofitting, reuse, Laurent Benoît Dewez. 


\section{Laurent Benoit Dewez and the construction of the detention centre [1]}

In 1773, empress Maria-Theresia of Austria declared the establishment of a 'modern' prison according to new standards concerning hygiene, health, natural ventilation and separate sections for men and women [2]. Consequently, an architectural competition for the construction of a new detention centre was organised by the Staten van Brabant on the plot of the demolished Ducal Fortress Prison in Vilvoorde [3]. Laurent Benoit Dewez (1731-1812), one of the leading $18^{\text {th }}$ century architects of the Southern Netherlands and the royal architect of Charles-Alexandre de Lorraine, won this competition. Dewez is widely known and appreciated for his renowned neoclassical abbeys, churches and castles in the Belgian context.

An enormous prison, the last major project by Dewez, was built on the left shore of the Zenne River surrounded by side canals and a non-aedificandi zone to guarantee maximum security. The stringent architecture combined efficient supervision and solitary confinement with aspects of correctional education and discipline: 'an immense sinister building situated near the canal. It is an enormous brick cube with large white plane façades perforated by small loophole like windows, evocating a sombre, disheartened impression.' [4].

During the execution of the project, surveyors of the Staten Van Brabant accused Dewez of serious building failures [5]. Even today some structural cracks in the masonry of the original walls demonstrate these statements. Nevertheless, the building was examined by the town-architect of Ghent, David 't Kindt [6], who concluded that these failures were rather insignificant and the detention centre was put into use on February 11, 1779.
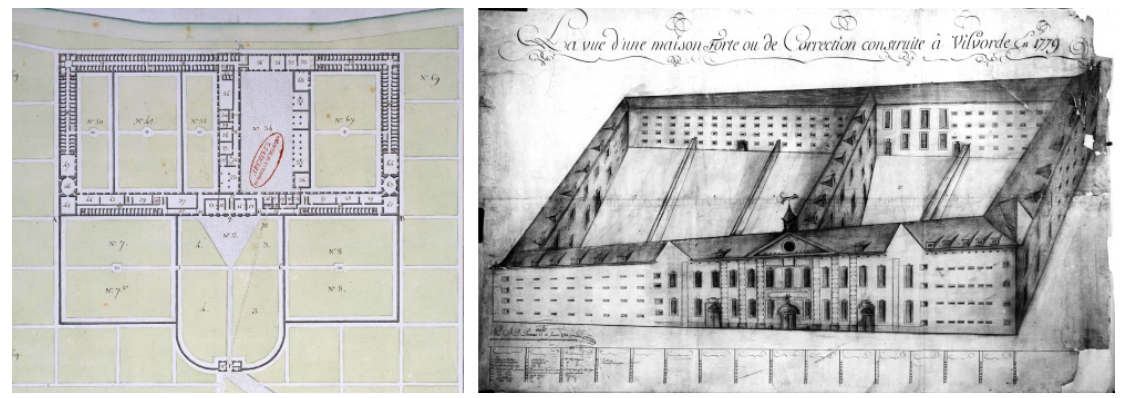

Figure 1: Plan of the original lay-out (right) and vision (left) of the detention centre made by Evereraert in 1787 [A. Wauters, illustration $\left.\mathrm{n}^{\circ} 192\right]$.

\section{Remarkable traces in the evolution of the detention centre}

The walled in and symmetric complex was accessible by a small entrance building. A forecourt, several courtyards and patios were used by the prisoners and the staff: a private garden for the prisons director and his staff, vegetable 
gardens, separate courtyards for men and women and separate patios for life sentenced prisoners and those who were only convicted for a limited period of time [7]. The façades of the prison wings are rather uniform and sober. Regardless of the elevations of the communal and service wings, distinctive series of small loophole like windows characterize the four-story high building.

Depending on the turbulent political or military situation, the objective of the detention centre changed substantially in the course of time [8]. During the French Revolution the complex was temporary used as hospital, retreat for vagrants and beggars and field hospital for the French troops. In the early $20^{\text {th }}$ century the prison was reused for the Lieutenant Van Lerberghe barracks. During the First World War, the complex was confiscated by the German military forces and became the Kaiserlich Deutsches Zentralgefangenes. After the war, the centre became a military facility up till 1974 and finally, the city of Vilvoorde bought the complex in 1981 .

Numerous transformations, extensions and calamities, such as a fire during a breakout in 1827 and an explosion in 1919, left their traces [9]. But fortunately, some traces are elegant and aesthetic, amongst them, the unique graffiti, representing in a fascinating way insight into the isolated lives of individuals and groups.

\section{Architectural paint research}

In 2005 an architectural paint research was executed in the cells of one of the 18 th century wings of this former prison [10]. On the walls of these extreme small vaulted cells (ca. 3,5 $\mathrm{m}^{2}$ ), graffiti was exposed on different levels of the thick lime wash packet (up to 15 layers). With their fingernails or with instruments at the disposal of the prisoners, most drawings were gouged into the surface. Also traces of pencil and paint were discovered. A striking collection of figures, animals, text, inscriptions, names, dates, doodles, countdown stripes, etc., decorates the cell walls. These long-hidden inscriptions show a funny, elegant, melancholic, hopeful, hideous, robust, aggressive and often shabby message. The graffiti became remarkable architectural ornaments these days.
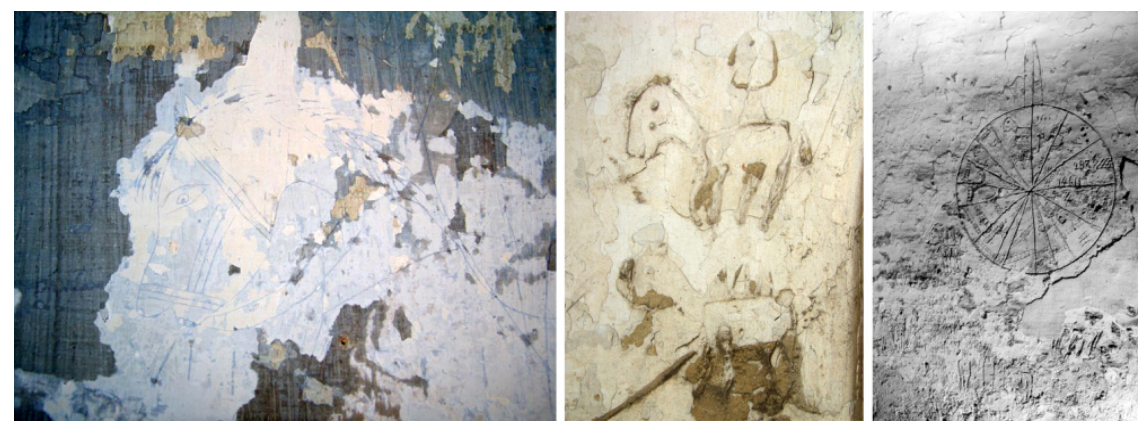

Figure 2: Horses scratched into the lime layer (left and middle), medallion scratched into the lime layer (right) [photos (CAnn Verdonck, 2005]. 
The methodological issues that arise from the use of architectural paint research explore the history of the interior as a site, in which everyday life is experienced and performed.

Comparable to this collection, similarly traces of graffiti can be found in other cases. For example in the Citadel of Gozo, a prison on a small island of the Maltese archipelago which was in use from the mid- $16^{\text {th }}$ century until the beginning of the $20^{\text {th }}$ century. The cells and corridor walls are also decorated with graffiti, representing stars, names and dates, silhouettes of hands and striking examples of old vessels, curved into the local sandstone. Again a striking collection of historical references in which memories were produced. Today, the individual cells, locked by massive doors and heavy locks, are wellpreserved in their original state and the old prison is reused as a permanent exhibition on fortifications to be found on the Island of Gozo [11].
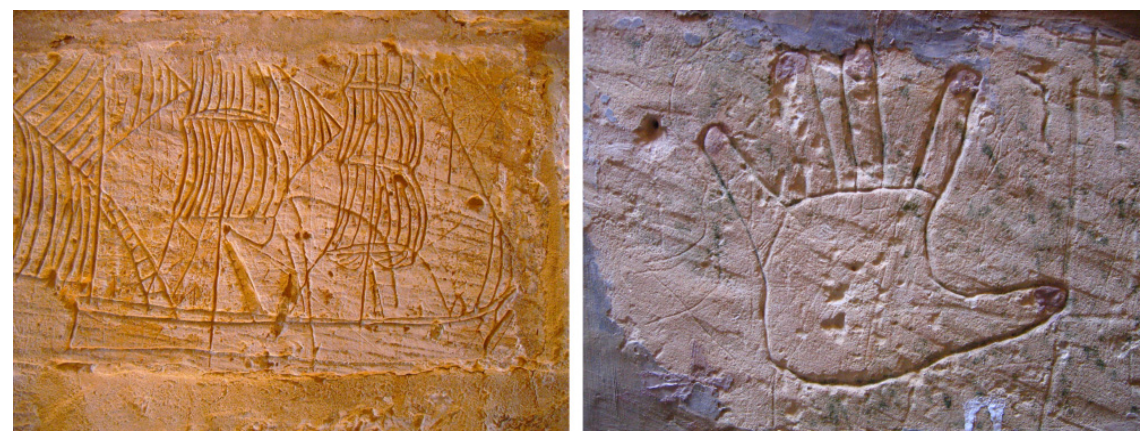

Figure 3: Photo of a sailing ship carved in the sandstone walls, old prison Island of Gozo (left), (right), silhouette of a hand carved in the sandstone walls, old prison Island of Gozo [photos (A)Ann Verdonck, 2008].

\section{Restoration tests in one of the prison cells}

As a result of the abominable state of preservation of the cell decorations in the Detention Centre in Vilvoorde, emergency fixations and restoration tests were executed in 2007 [12]. When comparing photographs of 1969 with those of the research in 2005 and the photographs made at the beginning of the emergency interventions, an alarming difference appears. Lack of occupancy and the pollution by a growing population of pigeons have left their traces. Lack of occupancy, combined with the pollution of the growing population of pigeons, have left their traces.

By means of a restoration test, one of the most decorated but endangered cells was treated. On the walls of cell $n^{\circ} 15$, situated on the first level of one of the prison wings, a fine medallion, groups of people and little horses are curved into the lime wash. In this cell we came across an extremely complex matter because of a complete adherence failure. The in-between joining of the thin lime wash layers, the bond between the lime wash and lime mortar and not at least the 
adherence of the lime mortar to the masonry, seemed to be problematic. Besides the lack of adherence we had to deal with pulverizing of the lime wash and salt contamination, both with serious consequences for the readability of the whole. To guarantee a solid deontological restoration approach, the maximum consolidation and preservation of the different paint layers and the graffiti within their original historical cell context, was obtained.

After several restoration test-strips, the fixation and consolidation methods were stipulated and modified. Fixation and consolidation of the surface was achieved by spraying Primal $(0,5 \%$ concentration in water) repeatedly on the wall. Small slivers of the lime wash were fixed with Mowilith $(2 \%$ concentration in water) and, when necessary, pressed with a hot spatula.

The pulverization was carefully brushed off and the subsoil was fixed with casein lime wash. Lacunas were only filled in with lime mortar at surfaces without any graffiti. By means of these completions, the wall ground became muted and the readability of the whole improved.

In order to consolidate the lime wash packet and the lime mortar, small 'bridges' were implemented before the injection of casein lime wash and liquid lime mortar. Subsequently on the surface two layers of Japanese fixation paper were pasted on the surface with methyl cellulose glue (type Tylose). The casein lime wash and liquid lime mortar were injected through the paper into the flaking lime wash.
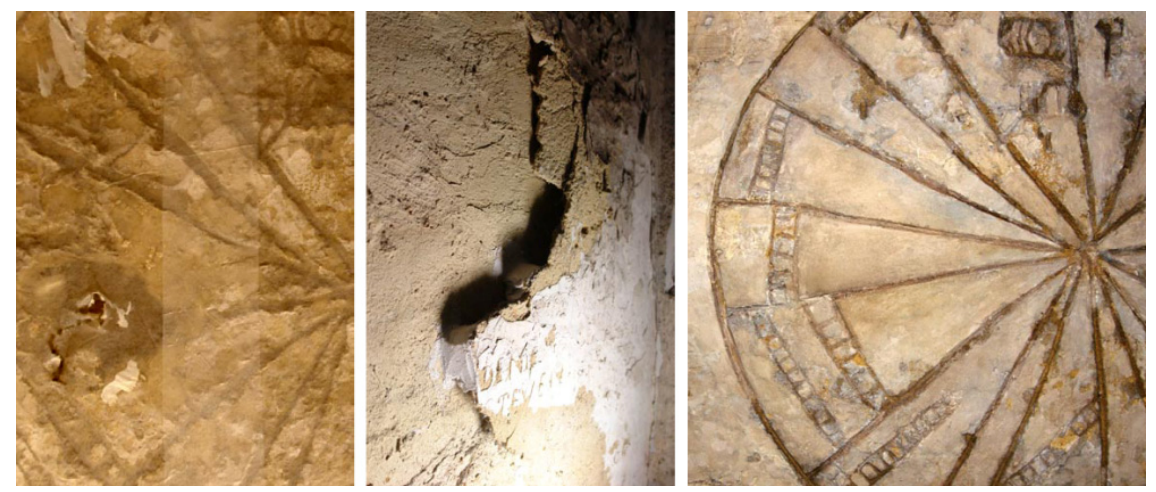

Figure 4: Facing with Japanese paper (left), implementation of a 'bridge' in preparation to the injection of casein (middle), after consolidation and retouching (right) [photos (CAnn Verdonck, 2007].

The methodology and products used in the restoration test-strips were extrapolated to the other walls of cell $n^{\circ} 15$. Considering the fact that the flaking of the lime wash layers of the medallion was about five centimetres, wheat starch and water were used instead of Tylose to hold the Japanese fixation paper to the wall. Only the white lacunas in the area of the medallion were retouched with aquarelle, with the idea to integrate the new fillings without being conspicuous.

Salt contaminations in the plinth, especially on the wall below the window, were brushed off and cleaned up. The black plinths (bitumen-paint) were 
originally painted in white lime wash. A black lime mortar was chosen to complete de lacunas of the plinth to get a visual total concept. The idea of reconstructing the plinths painted black in bitumen-paint would result in a very raw image, which doesn't follow the philosophy of maximal conservation and which doesn't show the history of the cell's walls.
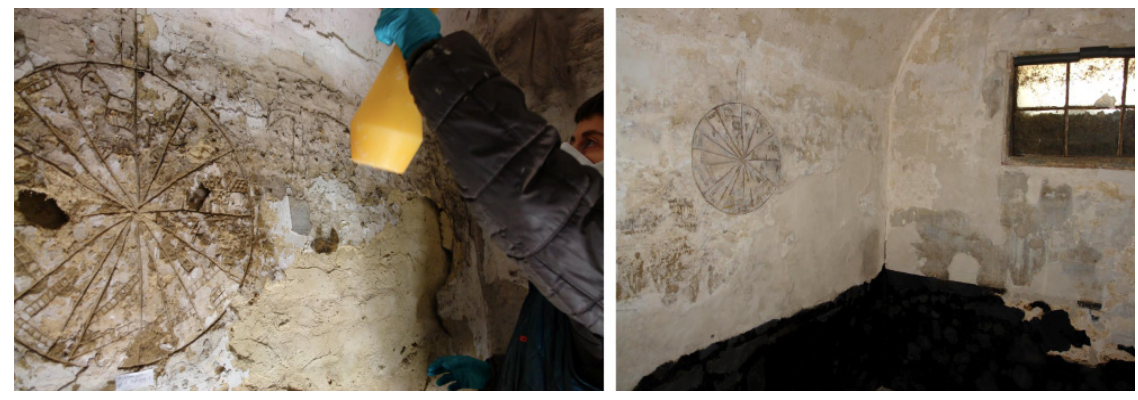

Figure 5: Fixation and consolidation of the surface of cell $n^{\circ} 15$ by spraying Primal (left), cell $\mathrm{n}^{\circ} 15$ after consolidation (right) [photos $@$ Ann Verdonck, 2007].

\section{Retrofitting and reuse of the detention centre}

The restoration of the Detention Centre fits in with the large-scale development of the former industrial zone near the Brussels-Antwerp Canal. The city of Vilvoorde worked out an ambitious redevelopment plan for the old industrial site in connection to both Vilvoorde as well as to the nearby city of Brussels. The intention was to reorganize, clean and transform the large industrial site into a mixed complex of housing, working, recreation and culture. A joint venture between the City of Vilvoorde, the Flemish Government and several private partners was established for this purpose. In the master plan, the former industrial site was conceived as a green pole with the presence of the water as the driving force behind the major lay-out. The reuse and retrofitting of the old prison complex was clearly a surplus value in this master plan. Implementation of consumer-minded and cultural functions into the complex was used as a trigger for the benefit of a more positive perception of the canal zone and of Vilvoorde in general. Supported by the historical values of this remarkable heritage, the socio-cultural wing, together with the new museum will become the tactical units of the complex allure.

This large-scale urban reuse project gave cause for the listing of the Detention Centre as a monument [13]. Therefore, the building not only acts as an important trigger for the urban development, it was safeguarded at the same time. The edit of the master plan as well as the reuse management were supervised and conducted by the Heritage Department of the Flemish Government [14]. At the Departments distinct request, the new-construction project evocates the original lay-out of the old Detention Centre. Due to a gunpowder explosion in 1919, the 
south wing of the prison was demolished but the new housing estate is a reminiscence of the former symmetric volumetric composition and its inner courtyards.

This proceeding improved the readability of the site improved subsequently and the remains of the prominent old prison building became again part of the urban setting. Several courtyards and patios are predestined for private and semiprivate use and a new public garden evocates the previous non-aedificandi zone between the prison complex and the city. In doing so, the restoration and preservation of the Detention Centre became anchored in issues concerning the recovery of memory, history, and community.
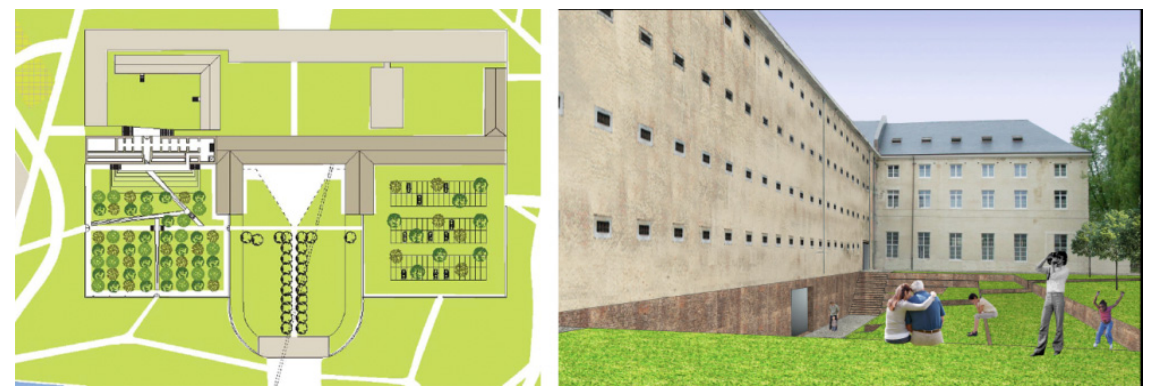

Figure 6: Evocation of the original lay-out in the new master plan: light grey for the new wings (left), simulation of the new entrance of the museum wing (right) [design (C) Grontmij-L'Escaut, Brussels 2010].

\section{Restoration of the museum wing: a work-in-progress}

For those wings where much of the interior structure and finishing was lost, a more radical restoration strategy was approved. These blocks were reused as a modern living and working area. Nevertheless these new functions were implemented with full respect for the $18^{\text {th }}$ century remaining building structure, spaces and prison cells.

The most intact wing, where the cells are well preserved, will serve as a museum, illustrating prison life in the $18^{\text {th }}$ century Detention Centre. Preoccupied with memory, commemorating the past and recovering the history of more than 200 years of confinement, the exposed graffiti is considered as a striking record of our social-cultural legacy. Therefore the architectural paint research and the preliminary restoration of prison cell $\mathrm{n}^{\circ} 15$ were crucial in preparation of the reuse assessment and to determine the determination of the preservation and conservation methodology.

The approach of a fundamentally 'light' restoration methodology was chosen in order to preserve the original disposition and characteristics of the future museum block and to consolidate its historic layers and finishes. The retrofitting of this particular wing also had to deal with technical, stability and programming issues, and the release to the public was of major importance. New additions were designed as contemporary transformable plug-in furniture respecting the 

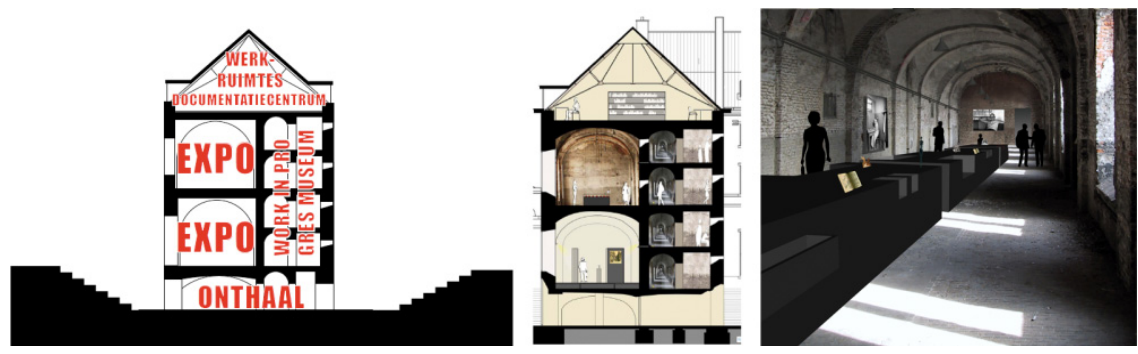

Figure 7: Organisation chart of the museum wing (left and middle), transformable plug-in furniture in the former workshop (right) [design (O)Grontmij-L’Escaut, Brussels 2010].

historic interior [15]. The completion of the museum program will be guided by suitable exploitation partners.

The further architectural paint research and consolidation of the 120 cells will be considerably time and money consuming. Therefore, the concept to engage the prison cells as an act of a work in progress to the future visitors, was established. Initial, the 10 most endangered cells will be treated and the used methodology will be extrapolated to the other 109 cells.

The architectural paint research in the cells and their consolidation will itself be a work of art on display. Students, archaeologists, historians as well as curious visitors shall contribute to the valorisation of this outstanding heritage. From this point of view, the historical values of the building as well the graffiti could be protected for the future generations in a unique way.

\section{Conclusion}

Notwithstanding the neglect and present state, the drawings in the Detention Centre are exceptional examples of naïve art, and form a curious and unique historical inventory. Architectural paint research was used in order to explore the cells of a group of prisoners during three centuries and these drawings will get the necessary attention in the reuse project of this extraordinary heritage. The restoration test in one of the cells will be used as guideline for the future restoration and re-establishing of these striking drawings and graffiti.

\section{References}

[1] D. Nuytten, Un Immense bâtiment, d' aspect sinistre, pose au bord du canal. Het voormalig tuchthuis van Vilvoorde, Monumenten \& Lanschappen, volume 25, no. 1, Brussels 2006, p. 6- 28.

[2] State Archives of Beveren (Belgium), inventory no. 53 of the archives of the detention centre of Vilvoorde (1776-1871) and the detention centre Sint-Bernardus of Hemiksem.

[3] A. Wauters, Histoire des environs de Bruxelles, volume 6B, Brussels 1972 (reprint 1855), p. 114-144. 
[4] J. Nauwelaerts, P. Crokaert, Histoire de la ville de Vilvorde, Paris 1941, p. 832: 'Un immense bâtiment, $d$ ' aspect sinistre, pose au bord du canal. $C$ 'est un énorme cube de maçonnerie percé de petites ouvertures dont les façades, grandes surfaces plates et blanches, piquées de noires meurtrières, produisent une impression attristante.'

[5] A. de Behault de Dornon, Le château de Vilvoorde, la maison de correction et leurs prisonnières célèbres (1375-1918), Antwerp 1921, p. 145-152.

[6] David t' Kindt (1699-1770), town architect of Ghent (Belgium) and representative of the rococo style, practised his profession mainly in Ghent.

[7] Cfr. Supra A. Wauters, p. 192: survey of the detention centre by van Everaert in 1787.

[8] J. Vandenbreeden, A. Tansens, L. Nagels \& M. Terlinck, Het tuchthuiscomplex in Vilvoorde, Part 1: Building history, Architecture Archive - Sint-Lukasarchief VZW, December 2001.

[9] Schrooten I. et al., Tuchthuiscomplex. Caserne du corps de discipline et de correction, unpublished paper of the centre for adult education, Development Monuments and sites, Antwerpen 2002, p. 10.

[10] A. Verdonck for Examino cvba, architectural paint research, October November 2005, executed under orders of the Architecture Archive - SintLukasarchief VZW.

[11] A. Verdonck, study-tour to Malta and Gozo, November 2008.

[12] Profiel cvba, restoration of one cell, January - February 2007, executed under orders of the Architecture Archive - Sint-Lukasarchief VZW.

[13] Decree of protection (25.01.2006), published in the Statute Book of Belgium (28.04.2006).

[14] Onroerend Erfgoed, Ruimte en Erfgoed, afdeling Vlaams Brabant.

[15] Grontmij-L'Escaut, Restoration of the museum wing of the detention centre in Vilvoorde, designed under orders of Dexia Bank NV and the City of Vilvoorde, March 2010. 